\title{
Managerial Decision on Strategic Objectives in Global Environment
}

\author{
Zaneta Rylkova ${ }^{1, *}$, and Jarmila Sebestova ${ }^{2}$ \\ ${ }^{1}$ Silesian University, OPF Karvina, Department of Business Economics and Management, Univerzitni \\ nam. 1734/3, 73340 Karvina, Czech Republic \\ ${ }^{2}$ Silesian University, OPF Karvina, Department of Business Economics and Management, Univerzitni \\ nam. 1734/3, 73340 Karvina, Czech Republic
}

\begin{abstract}
Managerial decision making is important in an enterprise and in leadership. Strategic objectives are, in general, objectives that an enterprise have to achieve to make its long-range plan that means a strategy succeed, especially in globalized environment. Each enterprise currently face the globalization that is why these enterprise have to know what can be done to achieve enterprise objectives more effectively within the future. The aim of the paper is to identify factors which can have an impact on decision making in the area of strategic objectives. Analysis shows the influence of selected variables such as financial performance, passion for work, managerial skills and communicated strategy on strategic objectives setting to be more open and dynamic or international. The paper is based on primary data collection from a recent survey of enterprises from the Czech Republic and on comparison with international resources focused on decision on strategic objectives. The primary research provides the support for relationships importance between selected variables for the managerial decision on strategic objectives. The secondary research introduces what specifically affects those variables. Moreover, the paper highlights that with managerial skills, a manager will assist the enterprise in achieving its objectives and business performance.
\end{abstract}

\section{Introduction}

Dramatic changes are affecting the global development. Examples include increased global competition, the impact of information technology, the re-engineering of business processes, smaller companies that employ fewer people, the shift from making a product to providing a service. These trends are producing a redefinition of decision making itself. The changes provide great opportunities for industrial and organizational researchers to contribute to the betterment of decision making on strategic objectives. This article identifies key areas in which to start in order to increase performance appraisal and organizational development. Relevant research in these areas can provide substantial payoffs for businesses and researchers.

\footnotetext{
*Corresponding author: rylkova@opf.slu.cz
} 
Improving entrepreneurial decision making is becoming one of the most important challenges to raising innovation, productivity and regional growth [15]. The present study supports the case for attention to entrepreneurs, it involved the following refinements (passion for work, organizational skills, tenacity, financial performance, conceptual skills, communicated strategy, self-efficacy) more oriented on abilities, skills and knowledge needed to grow an organization. The literature on managerial decision is starting to gain more attention, however, there is still a need to better understand how factors and variables can contribute to business development. Specifically, an important question that reflects a current gap in the literature is the area of skills and their importance on decision making on strategic objectives in global environment. The paper explore the theoretical background, the linkages between chosen factors (variables) based on the proposed research model linkages (see figure 1). The purpose of the paper was to provide a more understanding of the factors which influence the decision making on strategic objectives.

\section{Theoretical background}

Venture growth causes valued economic and social gains, including job creation, and venture growth is a measurable and well-understood venture goal and is explained as the essence of entrepreneurship in global environment [2, 4, 5]. Nowadays, many organisations position improving experience as a key strategic and operational objective. Decisionmaking is among the most important activities that managers engage in one a day to day basis, however, they do not always possess the necessary data to help them make the right decisions. Evidence-based practices improve the managers' skills in making decisions and encourages them to resort to systematic ways to do so [6].

Several theories and models have been developed over time to understand the personal and contextual factors that influence the managerial decision making on strategic objectives and business performance. The scientific literature on intention has dealt with two major lines of research, as follows: cognitive, regarding personal factors, and contextual or environmental factors [10].

New approaches to analyze the issue of personal characteristics and strategic management variables are focused on structural equation modeling revealed a web of relationships that impact venture growth in global environment [4]. GMM dynamic panel models were used in order to control for: endogeneity; time-invariant characteristics; possible collinearity between independent variables; effects from possible omission of independent variables; elimination of non-observable individual effects; and the correct estimation of the relationship between the dependent variable in the previous and current periods. The results from 199 Portuguesse family companies, from 2006 to 2014, confirm the hypothesis from literature, which argues that board diversity of external and internal factors is potentially positively related to firm objectives and firm performance. Also, the results show that region and sector of activity are factors influencing family firm objectives and performance. The study also confirms that company size and age are variables helping to explain companies' life-cycle. The study contributes to the literature on family firms regarding the effect of gender on family firm performance [7]. The concept of dynamic managerial capabilities is introduced in literature to underpin the finding of heterogeneity in managerial decisions and,firm performance in the face of changing external conditions $[1$, 4. 7, 10].

Rather than using broad categories or factors, researcher should use individual variables to analyze the effects and relationships among decision making characteristics [4]. Organizational factors and motivation have direct effects on business objectives, however, the effects of the train and skill composite factors were indirect through motivation and organizational factors [3]. 
Passion for work, or love of one's work, drive, emotional energy and spirit, have been identified in a qualitative analysis, as a core characteristics of great wealth creators [12]. Entrepreneur such as Bill Gates confronted opportunity and challenges with fervor and ardor. The enthusiasm for a type of business - the zeal for work - was so intense that they worked through financial barriers and challenges to the new products and the new ways of marketing [4].

Organizational skill involves managing established resources in established settings. Entrepreneurs' success efforts to arrange and organize resources are predictors of venture goals $[9,16]$. Thus, direct effects upon venture growth can be hypothesized.

Tenacity, or perseverance, is a trait that involves sustaining goal-directed action and energy even when facet with obstracles [4]. Researchers did not study whether tenacity is related to goals amond entrepreneurs. Entrepreneurs who hold stubbornly to their goals and who hate to give up increase their chances of start-up survival and success [17].

Entrepreneur-CEOs who have conceptual skills that means that he or she is able to analyse issues, is able to make decisions, to manage projects, read external and internal environment, and he or she has strategic thinking will recognize his or her competency and will hold beliefs about his or her ability to create and guide business goals to growth.

Communication of the business plan or strategy is as important as business plan content alone for developing better goals. Entrepreneurs may communicate their strategy through their written presentations or more dicrectly through speeches. Communicated strategy may help align entrepreneur-employee goals [13].

Desire for freedom and success, appetite for risk taking, organizational skills, goals, self-efficacy, and communicated vision had direct effects on venture growth, and these factors mediated the effects of passion, tenacity, and new investment spending on subsequent growth as was also examined in a qualitative study focused on Japanese firms in the study of [14].

An entrepreneur who recognizes that he or she has insufficinet confidence about financial performance may reflect the deficiency by setting lower goals. Those who believe they have high levels of confidence abou financial performance should be confident enough to set high goals [4].

\section{Methodology}

Authors of this paper were inspired by theoretical background to propose a research model with hypotheses as is illustrated in the figure 1. Conceptual skills enable individuals to achieve goals due to their understanding and can play an important role in manager performance [8]. This research admits that studies that regard conceptual skills and financial performance as factors that nurture business development are rare factors involved in surveys. The suggested model aims to close this gap and that is why conceptual skills and financial performance were included into the research. 


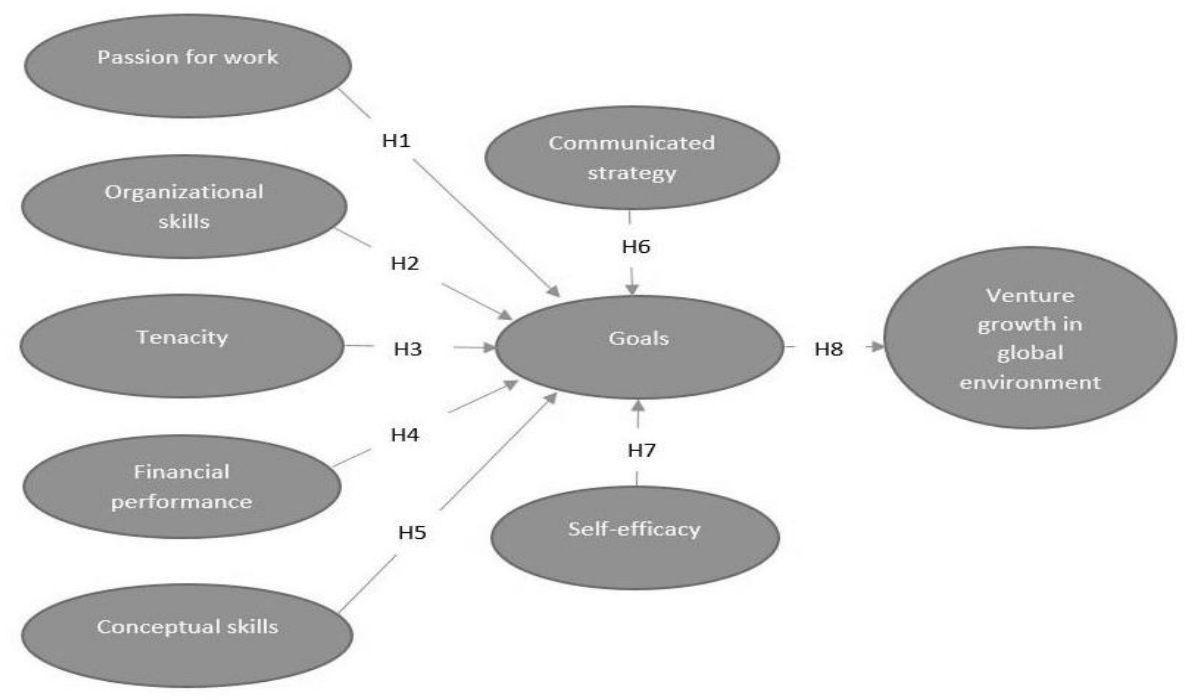

Fig. 1. Proposed research model

Based on the above introduced theoretical background, the primary research hypothesized:

H1: The greater the entrepreneur-CEO's passion for work is, the higher the goals for subsequent venture growth will be.

H2: The greater the entrepreneur-CEO's organizational skill is, the greater the goals for subsequent venture growth will be.

H3: The greater the entrepreneur-CEO's tenacity is, the greater the goals for subsequent venture growth will be.

H4: The greater the confidence about financial performance is, the greater the goals for subsequent venture growth will be.

H5: The greater the conceptual skills are, the greater the goals for subsequent venture growth will be.

H6: The greater the communicated venture growth content of entrepreneur-CEO's business plan is, the greater the goals for subsequent venture growth will be.

H7: The greater the self-efficacy for subsequent venture growth is, the greater the goals for subsequent venture growth will be.

H8: The higher number of the entrepreneur-CEO's goals for venture growth are, the higher the subsequent venture growth will be.

The primary research was conducted and the objective was to analyse economic literacy of business entities. Several factors affect the decision making on strategic objectives. Aspects studied and discussed within this paper are passion for work, organizational skills, tenacity, financial performance, conceptual skills, communicated strategy, self-efficacy. Students of the Silesian University, School of Business Administration were asked to return a response card if they were willing to participate. The students attended a training in order to introduce them the full process of the primary research in order to become adequately acquainted with their role-performing responsibilities. When the students felt that the rating was not sufficient to explain the experience fully then they included some added information of respondents. Ninety-one CEOs and sixty-five employee-participants agreed 
to participate. Within this paper seven predictor concepts were used (passion for work, organizational skills, tenacity, financial performance, cenceptual skills, communicated strategy, self-efficacy), and two control variables (size, age). The research team members created and changed or explained questions within this survey by using a draft questionnaire and with help of five CEOs and three employee-participants and their suggestions they made during subsequent structured interviews the final version of questionnaire was prepared. All of the data for measurement of independent variables were collected in 2019. We disqualified twenty-nine CEO responses from total ninety-one responses and ten employee-participants from sixty-five (founders CEOs who were not the same active owner-manager, those who supplied incomplete data). We accepted employeeparticipants because they had worked with their matching qualified entrepreneur- CEOs for twelve months or more, had submitted complete data, and had reported that they knew their CEO well. The total research sample was 117 respondents.

This study used data processing techniques with Categorical Data Analysis processed using SPSS software. According to [11] the sample size for Categorical Data model analysis ranged between $100-200$ respondents. When the sample is too large, then using this method will be very sensitive so it is difficult to get the goodness of fit result as good fit. The data were collected and made with Likert measurement scale with scale of one to five. The research was guided by the review of the literature and the aspects discussed earlier. Measurement of concept passion for work was adopted from [4, 12], organizational skills were adopted from authors $[4,5,14,16]$, tenacity was used from $[4,17]$, financial performance was adopted from [4], communicated stratedy from [4, 14], self-efficacy from $[4,14]$. The mentioned areas are already theoretically explained and empirically tested aspects that are believed to influence the intention to start an enterprise. Conceptual skills were added as a new aspect with an influence on venture growth.

Reliability test result is Cronbach alpha values greater than 0.81 , and inter-rate reliability 0.87 , it means reliable $[11]_{2}$ indicators of passion for work, organizational skills, tenacity, financial performance, conceptual skills, communicated strategy, self- efficacy can be said to be reliable for data collection.

\section{Analysis and results}

Participants in the survey evaluated the answers to the questions on the scale one to five. As seen in the table Czech entrepreneurs indicated mentioned factors as moderately high levels of entrepreneurship decision making process on strategic goals.

In the table one, a simple description of influential factors is introduced.

Hypotheses 1, 2, 4, 5, 6 and 8 were confirmed by the Cramer's V Value. Authors did not confirm hypothesis 3 ,The greater the entrepreneur-CEO's tenacity is, the greater the goals for subsequent venture growth will be.“ and hypothesis 7 „The greater the selfefficacy for subsequent venture growth is, the greater the goals for subsequent venture growth will be." The categorical analysis provided answers to the hypotheses. 
Table 1. Descriptive statistics

\begin{tabular}{|l|l|l|l|l|l|l|}
\hline & Minimum & Maximum & Mean & $\begin{array}{l}\text { Standard } \\
\text { Deviation }\end{array}$ & Median & Mode \\
\hline $\begin{array}{l}\text { Passion for } \\
\text { work }\end{array}$ & 1 & 5 & 2.77 & 1.002 & 3 & 3 \\
\hline $\begin{array}{l}\text { Organizational } \\
\text { skills }\end{array}$ & 1 & 5 & 3.52 & 0.728 & 4 & 4 \\
\hline Tenacity & 1 & 5 & 3.25 & 0.720 & 4 & 4 \\
\hline $\begin{array}{l}\text { Financial } \\
\text { performance }\end{array}$ & 1 & 5 & 2.73 & 0.871 & 3 & 3 \\
\hline $\begin{array}{l}\text { Conceptual } \\
\text { skills }\end{array}$ & 1 & 5 & 2.63 & 0.665 & 3 & 3 \\
\hline $\begin{array}{l}\text { Communicated } \\
\text { strategy }\end{array}$ & 1 & 5 & 3.30 & 0.604 & 3 & 3 \\
\hline Self-efficacy & 1 & 5 & 2.99 & 0.573 & 4 & 4 \\
\hline Goals & 1 & 5 & 2.76 & 0.773 & 4 & 4 \\
\hline Size & 1 & 79 & 14.91 & 12.165 & 26.50 & 28 \\
\hline Age & 1 & 10 & 5.34 & 2.537 & 5.50 & 4 \\
\hline
\end{tabular}

All variables the authors screened to reveal their distribution through Pearson correlation coefficients deviations for the variables (see table 2).

Table 2. Correlation coefficients.

\begin{tabular}{|c|c|c|c|c|c|c|c|c|c|c|}
\hline & $\mathrm{G}$ & $S$ & $\mathrm{~A}$ & $\mathrm{P}$ & OS & $\mathrm{T}$ & FP & $\mathrm{CS}$ & $\mathrm{COS}$ & $\mathrm{S}$ \\
\hline Goals(G) & 1 & & & & & & & & & \\
\hline Size $(\mathrm{S})$ & $\begin{array}{l}- \\
0.413 \\
* *\end{array}$ & 1 & & & & & & & & \\
\hline Age (A) & $\begin{array}{l}- \\
0.422 \\
* *\end{array}$ & $\begin{array}{l}0.317 \\
* *\end{array}$ & 1 & & & & & & & \\
\hline $\begin{array}{l}\text { Passion for } \\
\text { work (P) }\end{array}$ & $\begin{array}{l}0.333 \\
*\end{array}$ & 0.163 & $\begin{array}{l}0.218 \\
* *\end{array}$ & 1 & & & & & & \\
\hline $\begin{array}{l}\text { Organizational } \\
\text { skills (OS) }\end{array}$ & $\begin{array}{l}0.349 \\
* *\end{array}$ & 0.072 & $\begin{array}{l}0.328 \\
* *\end{array}$ & $\begin{array}{l}0.264 \\
*\end{array}$ & 1 & & & & & \\
\hline Tenacity $(\mathrm{T})$ & $\begin{array}{l}0.394 \\
*\end{array}$ & 0.043 & $\begin{array}{l}0.155 \\
*\end{array}$ & $\begin{array}{l}0.314 \\
* *\end{array}$ & $\begin{array}{l}0.276 \\
*\end{array}$ & 1 & & & & \\
\hline $\begin{array}{l}\text { Financial } \\
\text { performance } \\
\text { (FP) }\end{array}$ & $\begin{array}{l}0.489 \\
* *\end{array}$ & 0.053 & $\begin{array}{l}0.144 \\
*\end{array}$ & $\begin{array}{l}0.442 \\
* *\end{array}$ & $\begin{array}{l}0.331 \\
* *\end{array}$ & $\begin{array}{l}0.430 \\
*\end{array}$ & 1 & & & \\
\hline $\begin{array}{l}\text { Communicated } \\
\text { strategy (CS) }\end{array}$ & $\begin{array}{l}0.461 \\
* *\end{array}$ & 0.121 & $\begin{array}{l}0.202 \\
*\end{array}$ & $\begin{array}{l}0.506 \\
* *\end{array}$ & $\begin{array}{l}0.299 \\
* *\end{array}$ & $\begin{array}{l}0.446 \\
* *\end{array}$ & $\begin{array}{l}0.239 \\
* *\end{array}$ & 1 & & \\
\hline $\begin{array}{l}\text { Conceptual } \\
\text { skills (COS) }\end{array}$ & $\begin{array}{l}0.502 \\
* *\end{array}$ & 0.081 & $\begin{array}{l}0.179 \\
*\end{array}$ & $\begin{array}{l}0.479 \\
* *\end{array}$ & $\begin{array}{l}0.267 \\
* *\end{array}$ & $\begin{array}{l}0.199 \\
* *\end{array}$ & $\begin{array}{l}0.253 \\
* *\end{array}$ & $\begin{array}{l}0.511 \\
* *\end{array}$ & 1 & \\
\hline $\begin{array}{l}\text { Self-efficacy } \\
\text { (S) }\end{array}$ & $\begin{array}{l}0.326 \\
* *\end{array}$ & 0.065 & $\begin{array}{l}0.171 \\
*\end{array}$ & $\begin{array}{l}0.323 \\
*\end{array}$ & $\begin{array}{l}0.197 \\
*\end{array}$ & $\begin{array}{l}- \\
0.491 \\
* *\end{array}$ & $\begin{array}{l}- \\
0.301 \\
* *\end{array}$ & $\begin{array}{l}- \\
0.147 \\
* *\end{array}$ & $\begin{array}{l}0.107 \\
*\end{array}$ & 1 \\
\hline
\end{tabular}

Note: * Correlation is significant at the 0.05 level, $* *$ correlation is significant at the 0.01 level

The hypotheses 1 to 8 were tested through categorical data analysis. The results of categorical analysis are involved in the table 3 . 
Table 3. Categorical data analysis.

\begin{tabular}{|c|c|c|c|c|c|}
\hline & Hypothesis & $\begin{array}{l}\text { Pearson Chi- } \\
\text { Square Value }\end{array}$ & $\mathrm{df}$ & $\begin{array}{l}\text { Cramer's V } \\
\text { Value }\end{array}$ & $\begin{array}{l}\text { Asymp. } \\
\text { Sign }\end{array}$ \\
\hline Size & & 42.128 & 13 & 0.712 & 0.000 \\
\hline Age & & 30.313 & 5 & 0.479 & 0.001 \\
\hline $\begin{array}{l}\uparrow \text { passion for work, } \uparrow \\
\text { goals }\end{array}$ & H1 & 30.027 & 9 & 0.452 & 0.000 \\
\hline $\begin{array}{l}\uparrow \text { organizational skills, } \\
\uparrow \text { goals. }\end{array}$ & $\mathrm{H} 2$ & 27.679 & 9 & 0.483 & 0.000 \\
\hline$\uparrow$ tenacity, $\uparrow$ goals. & H3 & 11.343 & 9 & 0.212 & 0.113 \\
\hline $\begin{array}{l}\uparrow \text { financial performance, } \\
\uparrow \text { goals. }\end{array}$ & $\mathrm{H} 4$ & 25.838 & 9 & 0.153 & 0.163 \\
\hline $\begin{array}{l}\uparrow \text { conceptual skills, } \uparrow \\
\text { goals. }\end{array}$ & H5 & 28.664 & 3 & 0.267 & 0.000 \\
\hline $\begin{array}{l}\uparrow c o m m u n i c a t e d ~ s t r a t e g y, \\
\uparrow \text { goals. }\end{array}$ & H6 & 30.616 & 3 & 0.395 & 0.000 \\
\hline$\uparrow$ self-efficacy, $\uparrow$ goals. & $\mathrm{H} 7$ & 11.241 & 9 & 0.132 & 0.020 \\
\hline$\uparrow$ goals, $\uparrow$ venture growth. & $\mathrm{H} 8$ & 29.779 & 3 & 0.144 & 0.000 \\
\hline
\end{tabular}

\section{Discussion}

This research contributes to literature focused on decision making on strategic objectives by providing some insight on how chosen constructs and their associations may influence the venture growth. The research suggests that passion for work, organizational skills, financial performance, conceptual skills, communicated strategy influence the setting of objectives and subsequent growth in global environemnt.

This study does not explain the overall variables that can affect the goal setting and venture growth. So that in the next study can be included other variables. However, from a practical perspective the study suggests that researchers should fully explore the mentioned variables in a more detailed way. Future research should use more representative data to test the generalizability of the finding of this research. For instance [4] hypothesized that self-efficacy and tenacity are direct predictors of subsequent goals setting, but this primary study provides contrary findings and did not confirm hypothesis 3 and 7 in this paper. Future research may want to investigate why the tenacity and self-efficacy had a weaker association with the goals on the sample of Czech companies. However it is possible to state that the current knowledge is a tool that can serve as a mapping instrument for a higher venture growth.

\section{Conclusion}

This paper can be seen as a source of evidence that can help improve the accuracy of decision making on strategic objectives via concrete insights, directly linked to respondent's experience. This is particularly relevant consideration that respondents from primary and secondary research see about mentioned variables very important features for 
goal setting and development. The success of goal setting hinges on multiple factors, including but not limited to passion for work, organizational skills, financial performance, conceptual skills, communicated strategy. Primary research of authors extends and refines theoretical background. This paper is an output of the science project of the Silesian University in Opava SGS 6/2018 "Economic Literacy of Business Entities".

\section{References}

1. R. Adner, C.E. Helfat, Corporate effects and dynamic managerial capabilities. Strategic Management Journal 24, 1011 (2003)

2. H.E. Aldrich, Organizations evolving (London: Sage, 1999)

3. J.R. Baum, E.A. Locke, K.G. Smith, A multidimensional model of venture growth. Academy of Management Journal 44, 292-303 (2001)

4. J.R. Baum, E.A. Locke, The Relationship of Entrepreneurial Traits, Skills, and Motivation to Subsequent Venture Growth. Journal of Applied Psychology 89, 587 (2004)

5. W.C. Borman, S.J. Motowidlo, Task performance and contextual performance. The meaning for personnel selection research. Human Performance 10, 99 (1997)

6. L. Daouk- Öyry, M. Alameddine, N. Hassan, L. Laham, M. Soubra, The catalytic role of Mystery Patient tools in shaping patient experience : A method to facilitate value cocreating using action research. PloS ONE 13 (2018)

7. E.G.S. Félix, D.S.T. David, Performance of family-owned firms : the impact of gender at the management level. Journal of Family Business Management 9, 228-250 (2019)

8. D. N. Gansen-Ammann, Political Skills and Manager Performance : Exponential and Asymptotic Relationships Due to Differing Levels of Enterprising Job Demands. Group \& Organization Management 44, 718-744 (2019)

9. A. Ingram, W.O. Peake, W. Stewart, W. Watson, Emotional Intelligence and Venture Performance. Journal of Small Business Management, (2019).

10. E. Kallas, Environment-Readiness Entrepreneurship Intention Model: The Case of Estonians and the Russian-Speaking Minority in Estonia. SAGE Open, 9, 1-15 (2019)

11. T. Khairani, T. Y. R. Syah, Influence of Service Quality on Loyalty of Outpatient Mediated by Relationship Quality in East Jakarta Hospital. International Journal of Economics, Commerce and Management 5, 552-564 (2017)

12. E. A. Locke, The prime movers (New York: Amacom, 2000)

13. E. A. Locke, Work motivation in the context of a globalizing economy (Mahwah, NJ : Erlbaum, 2001).

14. M. Matsuo, The Unlearning of Managerial Skills : A qualitative Study of Executive Officers. European Management Review 16, 303-315 (2019)

15. G. Secundo, P. Del Vecchio, G. Passiante, Creating innovative entrepreneurial mindsets as a level for knowledge-based regional development. International Journal of Knowledge-Based Development 6, 276-298 (2015)

16. J.K. Smith, R.L. Smith, Entrepreneurial finance (New York: Wiley, 2000)

17. J.A. Timmons, New venture creation: Entrepreneurship (Homewood, IL: Irwin, 2000) 